\title{
Die Woord van God by Luther
}

\author{
I W C van Wyk \\ Hoof: Hervormde Teologiese Opleiding \\ Tydelik-deeltydse dosent Departement Dogmatiek \\ en Christelike Etiek (Afd A) \\ Universiteit van Pretoria
}

\begin{abstract}
Luther's understanding of the Word of God

This paper attempts to show that Martin Luther is much more than a great personality from the past. He is in fact an important theological father of the Nederduitsch Hervormde Kerk. Our theology must be understood from the perspective of Luther's theology. A call is also made that theologians from the Nederduitsch Hervormde Kerk not turn their backs on Luther. This paper concentrates on Luther's understanding of the Word of God. It gives perspectives on historical developments in Luther's theology. It also discusses the following themes: the Bible as the Word of God, the relationship between Old and New Testament, the relationship between law and gospel, the position of the pope and the role of experience in understanding the Word of God.
\end{abstract}

\section{INLEIDING}

Die herdenking van Luther, 450 jaar ná sy dood, gee aan ons in die Nederduitsch Hervormde Kerk van Afrika die geleentheid om in dié groot Reformator iets mér as net 'n groot historiese figuur met ' $n$ indrukwekkende persoonlikheid te ontdek. Ek is daarvan oortuig dat talle teoloë in ons Kerk in hulle harte met die groot Duitse digter Goethe saamstem oor wat hy op die 22 Augustus 1817 van Luther gesê het: 'Unter uns gesagt, ist an der ganzen Sache nichts interessant als Luthers Charakter, und es ist auch das einzige, was der Menge eigentlich imponiert. Alles übrige ist ein verworrener Quark, wie er uns noch täglich zur Last fällt' (Pesch 1983:48). Hierdie referaat wil aantoon dat Luther inderdaad ons geestelike vader is, en dat ons eie teologiese tradisie daarom nie buite Luther om verstaan kan word nie. Verder sal dit sinvol wees om Luther toe te laat om krities op sekere ontwikkelinge in ons teologie in te speel. Dit kan ons moontlik net help om opnuut koers en rigting te kry. Op versoek konsentreer ek op Luther se verstaan van die Woord van God.

* Referaat gelewer op 19 November 1996 tydens die kongres van die Kerkhistoriese Genootskap van die Nederduitsch Hervormde Kerk van Afrika, op die kampus van die Universiteit van Pretoria. 


\section{DIE BYBEL AS WOORD VAN GOD}

By Luther was daar geen twyfel dat die Bybel die Woord van God is nie. Die interessante is dat hy die argument gevoer het dat die Bybel, as God se Woord, 'n boek van troos is. Luther (WA $10 \mathrm{I}, 2,75,3-7$ ) het in 'n adventspostille in 1522 gesê: ' $\ldots$ trosten mag keyn buch, denn die heyligen schrifft ...; denn sie fasset gottis wortt'. In teenstelling met soveel mense vandag (Ebeling 1983:16-38), was die Woord van God, soos dit in die Bybel voorkom, dus vir Luther 'n boek van groot waarde en betekenis aangesien dit ' $n$ boek van troos is. Die Bybel was vir Luther die bewys dat die nuwe wêreld reeds aangebreek het (Iwand 1983:203). Hierdie gedagte dat die Bybel die Woord van God is, aangesien dit 'n boek van troos is, het hy telkens weer herhaal. Ek verwys na enkele uitsprake. Een keer het hy gesê:

Was für eine köstliche Sache ist es, Gottes Wort in allen Dingen zu haben. Denn er kann ganz getrost sein, wenn er auch noch so sehr versucht wird. Ein anderer ohne Gottes Wort fällt aber notwendig in Verzweifelung, denn es fehlt ihm die himmlische Berufung. Er wird allein von der Eitelkeit seines Herzens getrieben.

$(1983: 11=$ WATR 534)

'n Ander keer het hy weer gesê:

Die heilige Schrift ist voll von göttlichen Gaben und (Heils) Taten. Alle Bücher der Heiden lehren eindeutig nichts vom Glauben, der Hoffnung und der Liebe, ja sie wissen nicht einmal davon. Sie sehen allein auf das Gegenwärtige ... In Summa: Die heilige Schrift ist das höchste, es ist ein göttliches Buch, voller Trost in allen Anfechtungen.

$(1983: 14=$ WATR 6276)

Die Goddelikheid van die Bybel het dus vir Luther voortgespnit uit sy boodskap, naamlik sy woord van troos. By Luther kom 'n mens niks teë van die latere Ortodokse inspirasieleer ${ }^{1}$ wat die Bybel as verlengstuk van God gesien het nie. Nie as verlengstuk van God is die Bybel Woord van God nie, maar as sy boodskap van troos. In 1525 sê hy in De servo arbitrio: Duae res sunt Deus et Scriptura Dei, non minus quam duae res sunt Creator et creatura Dei/'God en die Skrif is twee (verskillende) dinge, niks minder as wat Skepper en skepsel van God twee (verskillende) dinge is nie' (WA 18, $606,11-12$ ). God en sy Woord is dus nie identies nie. Die Bybel bevat wel God se Woord, maar as boek is dit nie God se verlengstuk nie. 


\section{DIE BEDOELING MET STUDIE VAN DIE BYBEL}

Aangesien die Bybel God se Woord van troos bevat, was dit vir Luther 'n vanselfsprekendheid dat teologie met die studie van die Bybel sal begin en eindig. Studie van die Bybel was nie vir hom 'n doel in sigself nie, maar diens aan die prediking. Navorsing oor die Bybel wat nie die verkondiging dien nie, was vir Luther 'n mors van tyd. Teologie as die bestudering van die Woord van God, was vir Luther ook die koningin van die wetenskappe, aangesien dit die hoogste vorm van gemeenskapsdiens is. In sy eie woorde: 'Lasset uns die Bibel nur nicht verlieren, sondern sie lesen und predigen: denn wenn die Theologie blüht, so steht alles wohl und geht glücklich vonstatten. Denn sie ist das Haupt aller Fakultäten und Künste: wenn sie daniederliegt, so gebe ich alles andere auf (1983:11 = WATR 3589).

Teologie, as die belangrikste van alle wetenskappe, moet dus vir Luther die prediking op 'n voortreflike wyse dien, aangesien die prediking 'n geweldige invloed op die welwese van die hele samelewing het. Universiteitsteologie, as bestudering van die Woord, is dus reeds gemeenskapsdiens. 'n Teologiese fakulteit hoef dus nie nog gemeenskapsdiensprojekte te ontwerp om sy bestaan aan 'n universiteit te regverdig nie.

\section{PROFESSOR VAN DIE HEILIGE SKRIF 2}

Op grond van wat reeds gesê is, is dit vanselfsprekend om Luther by uitstek as die professor van die Heilige Skrif te betrag. In die Lutherse Ortodoksie was dit gebruik om vroeg in die dogmatiekhandboeke 'n locus de vocatione Lutheri ('n hoofstuk oor die roeping van Luther) te hê. In hierdie hoofstuk is Luther as die groot geroepene geskilder. Die bedoeling was om die persoonlikheidskultus rondom Luther te bestendig en om op grond daarvan, aan sy teologie legitimiteit en outoriteit te gee (Pesch 1983: 48). In 1928 het die Lutherse kerkhistorikus uit Münster, Karl Bauer, 'n wending in die Luthervoorstelling aangevoer toe hy die vraag gevra het: 'ob nicht etwa sein Beruf als Universitätsprofessor ihn ganz unvermerkt auf die reformatorische Bahn geführt habe?' (Pesch 1983:49). Vandag (Pesch 1983:49) is dit die algemeen geldende standpunt in die navorsing dat die 'Reformatoriese wending' by Luther primêr as 'n wetenskaplik-teologiese gebeure gesien word. Die Reformasie was dus 'n gebeure wat uit die Duitse universiteitsteologie gebore is. Reformatoriese geloof en teologie as wetenskap is twee kante van dieselfde muntstuk. Die gepraat oor ' $n$ teologiese opleiding verwyderd van ' $n$ universiteit is dus geheel en al onreformatories.

Luther was sedert 1512 professor vir die eksegese van die Heilige Skrif in Wittenberg. Hy was een van die min professore in daardie tyd wat oor ' $n$ doktorsgraad beskik het. Aanvanklik het hy Ou- en Nuwe Testament doseer. Sedert 1518, toe Philipp 
Melanchthon Nuwe Testament oorgeneem het, aangesien sy Grieks beter was, het hy op die Ou Testament gekonsentreer. Hy het egter wel in 1531 lesings oor Galasiërs, en daarná enkele ander lesings oor die Nuwe Testament aangebied.

In die jaar toe Luther professor geword het was Wittenberg universiteit 10 jaar oud. Daar was ongeveer 200 studente, waarvan 'n groot getal tussen 12-15 jaar oud was. Luther het self in 1509 vir 'n Bakkalaureat aan Wittenberg studeer, en het daarna geweldige probleme ondervind om by Erfurt daarvoor erkenning te kry. As kollegas het Luther verteenwoordigers van die Thomisme, die Skotisme en Okkamisme gehad. Die dekaan was Andreas Bodenstein von Karlstadt, sy latere vyand. Luther het die hele Wittenberg van gestalte laat verander. Teen 1517 kon die 2000 inwoners van die dorpie nie meer al die studente huisves nie. Teen 1518 het Melanchthon reeds 400 studente in Grieks gehad. Teen 1520 was hulle reeds 600 gewees. Dít alles, tot 'n groot mate, danksy die akademiese reputasie van Luther.

Maar wat het Luther dan as eksegeet gedoen, wat honderde studente na Wittenberg laat stroom het? Antwoord: hy het sy eksegese op ' $n$ heel besondere wyse beoefen. Hy het 'n tweevlak metode in die eksegese, soos wat ander reeds vóór hom gedoen het, gevolg. (a) 'Glossen' - Hy het die Bybelteks met spasies bokant en onderkant elke reël neergeskryf. In die spasies is daar aantekeninge (veral grammatikaal) oor elke woord geskryf. (b) 'Scholien' - Teksverse, perikope en selfs hoofstukke is sistematies behandel. Die noue en verre verbande is breedvoerig verduidelik.

Luther se eksegetiese metode en wyse van sistematiese nadenke oor die Skrif was moontlik gemaak deur die groot hervorming wat daar in daardie jare rondom teologiese universiteitstudie plaasgevind het. Die oortuiging dat die Aristoteliese filosofie ( = skolastiese filosofie), die versameling van pouslike dekrete, veral die Decretum Gratianus uit die 12e eeu (= kerkreg) en die Quatuor Libri Sententiarum van Petrus Lombardus (= dogmatiek) vir die teologiese opleiding belangriker as studie van die Skrif self was, is in die jare en dalk dekades voor Luther se aanstelling by die universiteit, al meer en meer betwyfel. Ernstige onvergenoegdheid is in daardie jare uitgespreek oor die leerplan wat begin het met 'n Baccalaureus Biblicus (BA Bybelwetenskappe) en wat dan opgevolg is deur 'n Baccalaureus Sententiarius (BA Dogmatiek) en dan geëindig het met 'n doktorsgraad in die teologie. In 1518 begin Luther dan om sy oortuigings, wat ook by talle ander geleef het, in praktyk te omskep. $\mathrm{Hy}$, wat in Wittenberg op die leerstoel van Staupitz aangestel is om Bybelse teologie en dogmatiek aan te bied, begin om slegs eksegese aan te bied, met inagneming van Augustinus en ander vroeg-skolastieke bronne. Met hierdie stap begin Luther om die hele teologiese opleiding te omvorm, en om só die kerk te hervorm. Waarop ons moet let is dat Luther daarvan afgesien het om eksegese te beoefen vanuit die diktatuur van die skolastieke 
dogmatisme. Wat hy egter nie gedoen het nie, was om eksegese los te koppel van die sistematies-teologiese (of dogmatiese) uitsprake van groot teoloë wat van wesenlike belang vir die leer van die kerk is. Eksegese moes vir hom ingebed bly in die groot teologiese tradisies van die kerk deur die eeue. - In daardie jaar (1518), nadat hy goed op stryk gekom het met sy werk, skryf hy aan sy Okkamistiese leermeester in Erfurt Jodocus Trutvetter die volgende:

Ich bin schlechterdings der Überzeugung, daß die Kirche unmöglich zu reformieren ist, wenn nicht von Grund auf die Canones, die Dekretalen, die scholastische Theologie, die Philosophie, die Logik, so wie jetzt betrieben werden, mit Wurzel ausgerissen und andere Fächer unterrichtet werden. Und in dieser Überzeugung gehe ich so weit, täglich den Herrn zu bitten, es möchte doch sofort geshehen, daß das völlig gereinigte Studium der Bibel und der heiligen Väter wiederhergestellt werde.

$$
(\mathrm{WABr} 1,170,33=\mathrm{nr} 74)
$$

Die hervorming van die kerk het dus met die hervorming van die teologiese opleiding begin. Alhoewel Luther die leiding geneem het om hierdie vernuwings daadwerklik deur te voer, moet weereens onthou word dat talle mense vór hom en rondom hom bygedra het tot die hervormings. Luther was dus die regte persoon op die regte tyd.

Die kerkhervorming het van die kateder plaasgevind. Luther se wetenskaplike eksegese, wat hand aan hand gegaan het met 'n bepaalde verstaan van die Skrif, het die reformasie van die kerk moontlik gemaak. Luther het daagliks eksegetiese lesings aangebied. Hy het in 1512 met lesings oor Genesis begin (wat ongelukkig verlore gegaan het). Vanaf 1513-1515 hou hy dan sy eerste lesings oor die Psalms, ook die Dictata super Psalterium genoem. Vanaf 1515-1516 is daar lesings oor Romeine. Van Oktober 1516-Maart 1517 hanteer hy 'n reeks lesings oor Galasiërs. Van Pase 1517-Pase 1518 hanteer hy die egte (!) Hebreërbrief van Paulus.

\section{EKSEGESE-SKOLASTIEKE TEOLOGIE}

In sy eerste Psalm-voorlesing het Luther nie van die Hebreeuse teks gebruik gemaak nie, maar van die Vulgaat, soos wat dit op daardie stadium, reeds oor honderde jare die gebruik was. Hy het ook as eksegetiese metode van die gebruiklike 'viervoudige Skrifbetekenis' gebruik gemaak. Volgens hierdie metode het, veral die Ou Testament, naas 'n literêre betekenis (wat grammatikaal-filologies vasgestel word), ook nog 'n diepere, of hoër, of geestelike betekenis (sensus spiritualis). Hierdie betekenis word in drie 
afdelings verdeel: die allegoriese, anagogiese en tropologiese betekenisse. Die allegoriese uitleg betrek die Ou Testament op Christus en sy kerk; die anagogiese uitleg betrek die tekste op die eskatologie; en die tropologiese uitleg betrek die Skrifwoorde weer op die etiek ${ }^{3}$. Hierdie eksegetiese metode lê ten grondslag aan 'n groot idee. Die grondgedagte is dat die heilsgeskiedenis in sy geheel, asook in sy detail, die resultaat van God se wysheidsplan is. Aangesien hierdie plan God se plan is, mag dit in sy skriftelike neerslag nie oppervlakkig betrag word nie. Elke gebeure moet in sy totaliteit van God se plan en sy wil betrag word. Hierdie eksegetiese metode wil dus verhoed dat God en sy geskiedenis vervlak word tot 'n beeld van 'n verwarrende klomp gebeure langs mekaar. 'n Bepaalde vers moet dus vanuit die totaliteit van God se wysheid verstaan word. Om hierdie rede het Thomas van Aquinas gesê: res significat aliam rem (Die saak/die vers beteken eintlik iets anders - of die eintlike betekenis van die vers moet nog uitgelê word). Net die sensus litteralis is 'n saak vir die wetenskap, aangesien die 'geestelike betekenis' 'n saak vir die geloof is. Geloofsinhoude word slegs deur die tradisie bepaal en kan daarom slegs deur die tradisie uitgelê word. Eksegese is dus vervlak tot 'n blote herhaling van 'n sekere mening uit die tradisie van die kerk. Teen hierdie wyse van eksegese het Luther hom gewend. Weereens! - Luther was nie die eerste teoloog om teen hierdie wyse van eksegese beswaar te maak nie. In die 12e eeu het Hugo van St Victor $(\dagger 1141)$ en in die 13e eeu Nikolaus van Lyra (1270-1349) die stryd teen hierdie wyse van eksegese gevoer. Nikolaus het 'n hele kommentaar oor die Bybel geskryf, genaamd die Postilla litteralis waarin hy aangetoon het dat mens nie aan elke vers ' $n$ geestelike betekenis kan koppel nie. Daar is in die navorsing gemeen dat Lyra Luther radikaal beinvloed het. Die spreekwoord het selfs ontstaan: si Lyra non lyrasset, Lutherus non saltasset/'indien Lyra nie op die lier gespeel het nie, sou Luther nie gedans het nie'. Dít is nie waar nie. Aanvanklik (by die eerste Psalmvoorlesing) wou Luther niks met Lyra se eksegetiese metode te make gehad het nie. Hy was bevrees dat hierdie metode dieselfde resultate as dié van die histories-kritiese metode van Erasmus sou oplewer, naamlik dat die Bybel as maar net nog 'n gewone boek beskou sou word. Ten spyte van sy vrees vir Lyra, het hy wel die noodwendigheid van die literêre eksegese aanvaar. Hy het egter besef dat mens nie met literêre eksegese kan volstaan nie, en het daarom 'n ander eksegetiese metode gevolg om die Psalms uit te lê. Hy het met 'n sensus litteralis propheticus ('n letterlik-profetiese betekenis) gewerk, wat hy van sy geestelike vader Staupitz geleer het. Aangesien die Psalms nie histories-letterlik van Christus kan praat nie, doen hulle dit wel profeties, maar nie op die vlak van die geestelike interpretasie nie, maar op die vlak van die literêre interpretasie. 
Luther het verder die oortuiging gehad, dat daar téén 'n mortua intelligentia/dooie verstaan van die Skrif gewaak moet word. Om hierdie rede was die tropologiese dimensie van uitleg vir hom van wesenlike belang. Hy het die tropologie egter nie tot die etiek beperk nie. Hy het die etiek met die letterlik-profetiese betekenis aangevul om op hierdie wyse tekste Christologies te verstaan met al die etiese konsekwensies wat daaraan gekoppel is. Hierdie was die eerste stappie in die rigting van die Reformatoriese Woordteologie (Pesch 1983:61).

In sy uitleg van die Romeinebrief kan mens egter 'n duidelike ontwikkeling in sy teologie sien. Hier het hy hom duidelik van die viervoudige betekenis van die Skrif gedistansieer. In 1532 het hy self in 'n Tischrede (WATR 1,335) gesê: 'Durch den Brief an die Römer kam ich zu einer gewissen Erkenntnis Christi. Dort sah ich keine Allegorien, [die sage,] was Christus bedeutet, sondern was Christus sei'. Alhoewel Luther die lesings in Latyn aangebied het, het hy Erasmus se Griekse teks gebruik. Om hierdie rede is dit ook nie vreemd dat mens in hierdie kommentaar dan talle positiewe uitsprake oor Lyra teëkom nie (kyk Pesch 1983:62 voetnoot 35 vir al die verwysings). Ten spyte hiervan het daar egter nog steeds in hierdie kommentaar, sowel as in die uitleg van die Boete-Psalms (1517), allegorieë voorgekom aangesien Luther getwyfel het of hy radikaal met die Quadriga moes breek. In elk geval is dit duidelik dat Luther reeds op hierdie stadium besluit het dat die 'geestelike betekenis' van 'n teks nie meer as begrondingsargument in die teologie gebruik kan word nie. Wanneer Johannes Eck hom in Julie 1519 in die disputasie van Leipzig op grond van Psalm 104:25 van die vaevuur wil oortuig, argumenteer hy dat mens Bybeltekste nie uit hulle verband kan haal en daaraan ' $n$ ander betekenis kan gee as wat die direkte konteks jou toelaat nie. 'n Verdere belangrike ontwikkeling wat hiermee hand aan hand gegaan het, was die moed wat by Luther ontwikkel het om die Skrif tot finale beslissings-instansie teen die kerklike outoriteit te stel. Die spreuk 'die Skrif alleen' (wanneer daar oor leeraangeleenthede (!!) beslis moet word), is natuurlik ook nie 'n oorspronklike gedagte van Luther nie. Hy (WABr 2, 602, 42) het byvoorbeeld in 'n brief aan Hieronymus Dungersheym (Eck se geesgenoot) ná die disputasie van Leipzig daarop gewys dat Augustinus ook die Skrif die laaste sê in leeraangeleenthede gegee het ${ }^{4}$. Trouens, Luther het hierdie argument alreeds in 1509 geken. In 'n randaantekening by Petrus Lombardus se 'dogmatiek' (WA 9, 46, 16) het hy al gesê dat die kerkvaders se menings nie belangriker as die Bybelse argumente kan wees nie. In die tweede Psalmvoorlesing het Luther net met sy nuwe hermeneutiek gewerk. Hy (WA 5, 75, 1) het op daardie tydstip gesê dat dit nie wenslik is om na al die uitsprake van al die kerkvaders te kyk nie, aangesien hulle allegoriese verklarings feitlik geen bydrae tot die verstaan van die tek- 
ste lewer nie. Luther het daarom by die punt uitgekom dat hy in sy eksegese hoofsaaklik met die literêre eksegese sou werk - selfs al sou dit die konsekwensie hê dat hy op 'n plek sou kom waar hy moet sê: hic meam confiteor ignorantiam/hier gee ek toe dat ek nie weet nie.

\section{DIE VERHOUDING: OU TESTAMENT - NUWE TESTAMENT}

Luther se nuwe eksegetiese metode kon egter nog steeds nie al die verstaansprobleme met die Bybel oplos nie. Een van die groot probleme wat hy moes hanteer, was die vraag na die verhouding van Ou- en Nuwe Testament. Die vraag aan Luther was: wat is die verband tussen die Psalms en Christus? Volgens Luther is daar 'n heel duidelike verband. 'n Psalm het sonder Christus geen betekenis vir die Christen nie. Die heilsbetekenis van Jesus, soos veral Paulus dit verstaan het, is vir Luther die hermeneutiese sleutel tot die Ou Testament. 'Tolle Christum e Scriptures, quid amplius in illis invenies/Neem Christus uit die Skrif: wat sal jy dan nog daarin (in hulle) vind?' (WA $18,606,29)$ het hy eenmaal uitgeroep. Sonder dat mens dit dag en datum kan vasstel (Pesch 1983:64) het hierdie 'Paulinisme' die wortel van die Reformatoriese teologie geword. Luther se beroemde uitdrukking dat mens Heilige Geskrifte daaraan erken 'ob sie Christum treiben' (WADB 7, 384, 27 = Voorrede tot die Jakobusbrief) kan dus maklik op die Psalms van toepassing gemaak word. Ook die Psalms 'treiben Christus' alhoewel hulle nie 'n woord oor Hom sê nie, aangesien hulle die God wat Hom in Christus as die Genadige geopenbaar het, ter sprake bring. Hierdie hermeneutiese perspektief geld vir die ganse verhoudingsvraagstuk tussen Ou- en Nuwe Testament. Volgens Luther het die Ou Testament slegs waarde vanuit die perspektief van die Nuwe Testament. Christus ontbloot veral die belofte-karakter van die Ou Testament. 'Das new testament ist nit mehr denn eyn offinbarung des allten, gleych alß wenn yemant tzum ersten eyn beschlossen brieff hette und darnach auffbrech' (WA $10 \mathrm{I}, 1,181,24-$ 182,1 ). Op 'n ander plek (WADB 8, 12, 5-8 = voorrede tot die OT 1523) sê hy van die Ou Testament: Hie wirstu die windeln vnd die krippen finden, da Christus ynnen ligt, dahyn auch der engel die hirtten weysset, Schlechte vnd geringe windel sind es, aber theur ist der schatz Christus, der drynnen ligt'. Luther se hermeneutiek kom dus neer op die volgende uitsprake: Omnia scripturae verba tendunt, ut Christus cognoscatur/'alle woorde van die Skrif streef daarna, dat Christus herken word' (WA 14, 97, 1 = preek oor Genesis 1523/24); en: Si vetus testamentum per humanum sensum potest exponi sine novo testamento, dicam quod novum testamentum gratis datum sit/'wanneer die Ou Testament met menslike insig sonder die Nuwe Testament verklaar kan word, sal ek wil sê dat die Nuwe Testament tevergeefs gegee sou wees' (WA 3, 12). 
Luther het ook besef dat 'n mens selfs nie eers met 'n Christologiese interpretasie van die Ou Testament kan volstaan nie. Hy het gemeen dat dit noodsaaklik en noodwendig is dat sekere uitsprake van die Ou Testament met behulp van die Triniteitsleer 5 ( $\mathrm{m}$ a w vanuit die perspektief van die totale heil van God/boodskap van die Bybel) verklaar moet word. Die bekendste geval is sy verklaring van die '... laat ons mense maak ...' van Genesis 1:26. Luther meen dat ons hier met 'n pluralis deliberationis te make het en dat die faciamus hominem 'n bevestiging van die misterie van ons geloof (die Triniteit) is, qua credimus ab aeterno unum Deum et distinctas tres personas in una divinitate, Patrem, Filium et Spiritum sanctum/'waarvolgens ons glo aan die God wat van ewigheid af één is, onderskeie in drie persone in die één Godheid, Vader, Seun en Heilige Gees' (WA 42, 43, 13-15). Letterlike eksegese en Trinitariese uitleg van die Skrif was vir Luther nie met mekaar in botsing nie - trouens dit moes mekaar op sekere plekke aanvul.

Ten spyte van Luther se breuk met die laat-Middeleeuse eksegese, is dit op die keper beskou só dat hy ten opsigte van die basiese idee nie van hierdie teologie kon en wou wegbreek nie. Ook hy het met die besef gewerk dat mens nie eksegese sonder dogmatiek' of sistematiese teologie kan beoefen nie. Eksegese is nie teologiese eksegese as dit nie met die Christologie en die Triniteitsleer - of anders gesê; met die totale werk van God - in verband gebring word nie. Luther het dus met sy teologiese tradisie saamgestem dat eksegese nie met 'n 'direkte verbandseksegese' kan volstaan nie ${ }^{6}$.

\section{WET EN EVANGELIE}

Luther het ook 'n ander geweldige groot bydrae ten opsigte van die verstaan van die Skrif gelewer. Hy het dit sy hele lewe deur beklemtoon dat daar tussen wet en evangelie onderskei moet word. In 1521 sê Luther (WA 7, 502, 34) in 'n preek: 'Nahezu die ganze Schrift und das Verstehen der gesamten Theologie hängen am rechten Verstehen von Gesetz und Evangelium'. Om wet en evangelie reg te verstaan, beteken vir Luther om hulle te onderskei. In sy groot voorlesing oor Galasiërs (1531) sê hy (WA 40 I, 207, 3-5): 'Wer diese beiden (Gesetz und Evangelium) recht zu unterscheiden weiß, soll Gott danken und wissen, daß er ein Theologe ist'. Op dieselfde trant sê hy (WA 36, 9, 28) in 'n preek in 1532, dat die regte verstaan van wet en evangelie in die onderskeiding van wet en evangelie lê, aangesien hierdie onderskeiding 'die höchste Kunst in der Christenheit' is. In die eerste disputasie teen die 'Antinomer'/wetsvyandiges (1537) sê hy (WA 39 I, 361, 1-6): 
Ihr habt es schon oft gehört, daß es keine bessere Kunst gibt, die rechte Lehre weiterzugeben und zu bewahren, als daß wir dieser Methode folgen, nämlich daß wir die christliche Lehre in zwei Teile teilen; eben in Gesetz und Evangelium. Dies sind die beiden Dinge, welche uns im Wort Gottes vorgelegt werden, nämlich entweder Gottes Zorn oder Gottes Gnade, Sünde oder Gerechtigkeit, Tod oder Leben, Hölle oder Himmel'.

Oppervlakkig beskou, kan die vermoede heers dat Luther Moses en Christus, Ou Testament en Nuwe Testament van mekaar wou verwyder. Immers! Hy hét uitsprake soos hierdie (Voorrede tot die Nuwe Testament in 1522) gemaak:

... gleych wie das allte testament ist eyn buch, darynnen Gottis gesetz und gepot, da neben die geschichte beyde dere die selben gehallten und nicht gehallten haben, geschrieben sind: Also ist das newe testament, eyn buch, darynnen das Euangelion ind Gottis verheyssung, danebe auch geschichte beyde, dere die dran glewben und nit glewben, geschrieben sind.

(WADB 6, 2, 16-20)

Wel wetende dat dít nie al is wat oor die Bybel gesê kan word nie, skryf hy dan in 1523 in die voorrede tot die Ou Testament dat daar in die Nuwe Testament naas die genadeleer ook wette en gebooie voorkom, en dat daar in die Ou Testament naas die wette etlike beloftes en genadespreuke voorkom (WADB 8, 12-15). Onderskeiding tussen wet en evangelie is daarom nie onderskeiding tussen die twee testamente nie, maar onderskeiding tussen wet en evangelie wat regdeur die Bybel voorkom.

Die vraag bly nou nog: hoekom wil Luther wet en evangelie uitmekaar hou? Hoekom wil hy verhoed dat wet met evangelie verwar word? Die rede: die wet kan nie red nie en die evangelie is geen wet nie. Die verkondiging van die wet (die morele wet), hoe belangrik dit nou ook al mag wees, is vir Luther nog steeds nie die eintlike saak waarom dit in die teologie gaan nie. Die eintlike saak vir Luther is die verlossing wat nie deur voortreflike moraliteit bewerk kan word nie. In sy Epistolam Pauli ad Galatas commentarius van 1519 het hy al die volgende gesê: 
Das Gesetz, und nicht allein das Zeremonialgesetz, sondern auch das Moralgesetz, und sogar der allerheiligste Dekalog der ewigen Gebote Gottes, ist Buchstabe und Buchstabenlehre, und macht weder lebendig noch gerecht, wie überreichlich der selige Augustinus in de spiritu et littera beweist, sondern tötet und läßt die Sünde mächtig werden, soviel es nur will; das Herz selber aber wird dadurch nicht rein. Wo aber das Herz nicht rein worden ist, was sind da alle guten Werke, die zeremonialischen wie die moralischen, außer ein bloßer Schein von Frömmigkeit, d.i. ist Heuchelei?

(WA 2, 468.33-38)

Sedelike voortreflikheid, hoe belangrik dit nou ook al mag wees, kan mens volgens Luther nie red nie. Die mens word slegs op grond van God se genade in Christus, soos in die Nuwe Testament beskryf, gered. Die Christen moet daarom noukeurig tussen wet en evangelie onderskei, sodat hy nie sy vertroue in verkeerde dinge en op verkeerde plekke gaan soek nie. Die mens moet sy heil in Christus waarvan die Nuwe Testament praat, gaan soek, en nie in morele gedrag wat op voortreflike wyse deur veral die Ou Testament geleer word nie.

Luther het met sy skerp onderskeiding van wet en evangelie radikaal met die Roomse tradisie van wet en genade gebreek. Augustinus het in sy geskrif $D e$ Spiritu et Littera gesê: Lex ergo data est, ut gratia quaereretur, gratia data est, ut lex impleretur/'Die wet is dus gegee sodat die genade gesoek kan word; die genade is gegee, sodat die wet vervul kan word'. Dit was juis hierdie skema wat Luther in 'n geloofskrisis gedompel het. Hy het die ervaring opgedoen dat hierdie skema jou al meer en meer oor jou saligheid laat twyfel, aangesien die mens nooit in staat is om aan al die verwagtinge van die wet te voldoen nie. Die evangelie kan dus nie maar bloot die hulp tot wetsvervulling, as die grond van jou redding, wees nie.

Maar wat is die funksie van die wet dan? Moet die wet dan nie gepreek word nie? Luther was cortuig dat die wet wel gepreek moes word. Maar met wetsprediking moet 'n mens versigtig wees aangesien die konsep 'wet' 'n veelhoekige saak is. Volgens Luther het ons die wet nie van Moses ontvang nie. Dit is nie eers 'n saak van ná die sondeval nie. Luther het dikwels gesê dat daar ' $n$ wet onder die engele was en dat Adam voór sy sondeval ook 'n wet gehad het. Dit was nou nie 'n voorskriftelike wet nie, maar ' $\mathrm{n}$ wet waaraan almal hulle vrywillig en met oorgawe onderwerp het (WA 39 I, 436, 2-4). Die punt is: Moses was vir Luther daarom nie die skrywer van die Dekaloog nie, maar ' $n$ uitlegger en verklaarder van die wet wat in elke mens se hart 
geskryf is (WA 39 I, 454, 4-16). Met die sondeval verander die situasie egter. Ná die sondeval word die mens nie meer deur die wet as innerlike rigsnoer gelei nie, maar deur die wet as uiterlike norm gedwing, aangekla en veroordeel. Luther hou nogtans daaraan vas dat selfs ná die sondeval elke mens iets van die wet af weet. Die natuurwet, soos hy dit dikwels noem, is daarom in die hart van elke mens geskryf. Elke mens weet dat jy nie mag steel, doodmaak en egbreuk pleeg nie.

Die natuur leer selfs ook 'wie die liebe thut, das ich thun soll, was ich myr wollt gethan haben' (WA 11, 279, 19-20). Om hierdie rede het Luther gesê: 'Ich fühle im Herzen, daß ich dies [die Erfüllung der Gebote] gott schulde, nicht weil der Dekalog im Blick auf uns überliefert und geschrieben ist, sondern weil wir wissen, daß wir diese Gesetze mit uns in die Welt gebracht haben' (WA 39 I, 540, 10-12). Dít beteken egter nie dat die wet nie gepreek hoef te word nie. Wetsprediking is noodsaaklik aangesien die natuurlike kennis van die wet nie toereikend is nie, en wel in dié opsig dat die natuurlike mens geen konsekwensies uit sy kennis van die wet trek nie. Daarom het hy gesê 'war und ist es immer notwendig, den Menschen jene Kenntnis des Gesetzes weiterzugeben, damit sie die Größe ihrer Sünde sowie den Zorn Gottes erkennen' (WA 39 I, 361, 19-22).

Luther het die wet (en spesifiek die dekaloog) gehoorsaam en gepreek, nie omdat dit die wet van Moses is nie, maar omdat dit 'n vernuwing van die natuurwet is. Luther wou daarom ook slegs met dié gedeeltes van die wet iets te make gehad het wat in wese 'n herformulering van die natuurwet is, terwyl hy niks met dié gedeeltes te make wou gehad het wat Joodse wette is nie. Luther het die oortuiging gehad dat die ganse Ou Testamentiese wet nie vir Christene kan geld nie, aangesien die Joodse volkswet - wat hy die 'der Juden Sachsenspiegel' noem (WA 16, 378, 11 en 18, 81, $14 \mathrm{vv}$ ) - net die Joodse volk aangaan. Teenoor die 'Schwärmer' sê hy 'das alle solche Mosische lerer das Euangelion verleucken, Christum vertreyben und das gantze newe testament auff heben. Ich rede itzt als eyn Christen und fur die Christen, Denn Mose ist alleyne dem Judischen volck gegeben und geht uns Heyden und Christen nichts an' (WA 18, 76, 2-5 = Wider die himmlischen Propheten 1525). Die implikasie is dat Luther geoordeel het dat die Joodse regs- en seremoniële wette nie vir Christene en heidene normatief kan wees nie. Ten spyte hiervan het Luther groot oordeel aan die dag gelê om nie 'n streep deur alles te trek nie. Hy het daarop gewys dat sake soos die Joodse jubeljaar en sabbatjaar nou nie as wet van God voorgehou kan word nie, maar dat dit nogtans navolgenswaardige voorbeelde van etiese ideale kan wees. Daar kan na goeddunke, van tyd tot tyd, besluit word om hierdie gedagtes aan kerk en samelewing voor te hou as navolgengswaardige etiese waardes (Lohse 1995:292). 
Die sedewet, of natuurwet soos dit in die Dekaloog en ander gedeeltes van die Ou en Nuwe Testamente na vore kom, moet volgens Luther gepreek word. Wanneer daar oor die wet gepreek word, moet daar egter duidelikheid oor die motief wees. 'n Mens moet weet wat met 'n spesifieke preek oor die wet bereik wil word. Volgens Luther kan daar by ' $n$ prediker een van drie motiewe wees. Hierdie drie motiewe staan in die Lutherse (en na-Lutherse) teologie bekend as die drie gebruike van die wet. Om oor die wet in terme van gebruik/usus te praat is 'n oorspronklike Lutherse prestasie (Ebeling 1960:58-66).

* Die eerste gebruik van die wet/usus legis primus

Die wet kan in die prediking gebruik word met die motief om 'n bydrae tot die orde, vrede en regssekerheid in die samelewing te lewer. Hierdie gebruik staan daarom ook bekend as die usus politicus of as die usus civilis. Die prediking van die wet het onder hierdie gebruik die bedoeling om die gebooie by almal in te skerp, die gewetens op te skerp en die regspleging te bevorder. Hierdie dimensie van die wetsprediking moet veral die amptenare van die wêreldlike owerhede, die ouers, die onderwysers en die regters aanspreek, aangesien hulle primêr vir orde, vrede en reg verantwoordelik is.

Die uitwerking wat hierdie wetsprediking het, is uiterlike of burgerlike geregtigheid, wat voor God (wat ten opsigte van ons heil) niks beteken nie. In sy tweede 'Antinomerdisputation' sê hy (WA 39 I, 459, 16-17): 'Die politieke geregtigheid is goed en prysenswaardig, alhoewel dit voor God nie kan bestaan nie'/ politica iustitia bona est et laudibus digna, etsi in conspectu Dei non possit consistere. Verder sê hy (WA 39 I, 441, 5-6): Die wêreldlike geregtigheid het sy eie eer en sy eie loon in hierdie lewe onder die mense, maar nie by God nie/ustitia mundi habet suam gloriam et sua praemia in hac vita inter homines, sed non apud Deum'.

* Die tweede gebruik van die wet/usus legis secundus

Vir hom was die tweede gebruik van die wet, die usus legis secundus of die usus paedagogicus, die eintlike saak van die kerk. Die kerk moet volgens hierdie gebruik die wet verkondig met die bedoeling om mense van hulle skuldverlorenheid te oortuig. Die wet, in sy geestelike gebruik, kla aan en veroordeel. Dit laat die 
mens besef dat hy voor God nie is wat hy behoort te wees nie. Die wet, in hierdie opsig, is dus 'n verskrikking, aangesien dit die ware wese van die mens openbaar (WA 39 I, 456, 19-457). Luther sê ook dat die tweede gebruik van die wet die bedoeling het om ' $n$ 'sonde vermeerderende funksie' te vervul. Die wetsprediking moet die sonde in sy verskriklikheid en omvangrykheid uitlig. Luther beskryf die werking van die wet daarom nie as causa efficiens nie, maar as causa ostensiva (WA 39 I, 529, 3-560). Hierdie geestelike gebruik van die wet lewer ook nie 'n bydrae tot die geregtigheid van die mens nie; dit openbaar slegs die toorn van God oor die sonde. Die wet, wat gereeld in hierdie sin aangehoor word, moet die mens van sonde oortuig en hom op hierdie wyse na die arms van Christus dryf. Hy moet na aanleiding van hierdie wetsprediking besef dat dit net die regverdigverklarende woord van Christus is wat heil kan bewerk (WA $39 \mathrm{I}, 456,7-8$ ).

* Die derde gebruik van die wet/usus legis tertius

Ten spyte daarvan dat Melanchthon sedert die dertigerjare van die 16e eeu die leer oor die drie gebruike van die wet verkondig het, het Luther hierdie leer nie terminologies of saaklik verdedig nie. Afgesien van een plek in die 'Kirchenpostille' van 1522 (WA 16, 373, 12; 375, 14) waar daar van 'dreyerley brauch des gesetzs' gepraat word, word daar net een verdere plek gevind waar Luther (?) ${ }^{7}$ hierdie formule gebruik het, naamlik aan die einde van die 'Antinomerdisputation' van 1538. Luther se huiwering om te veel van die derde gebruik van die wet te maak is te wyte aan sy oortuiging dat ' $\mathrm{n}$ Christen eintlik nie die wet as sedelike riglyn nodig het nie, aangesien hy wét wat reg en verkeerd is, omdat hy vry is. In 1521 skryf hy:

Der buchstab [d $\mathrm{i}$ die OT] ist nichts anders denn das GESETZ ON GNADE. Also mügen wir widerumb sagen, das der geyst [d $i$ die NT] sey nit anders denn die GNADE ON GESETZ. Wo nu der buchstabe ist oder gesetz on gnade, da ist keyn auffhören gesetz machen, leren und wircken, und hilfft doch nichts, wirt niemant davon besser, bleybet alles todt ym buchstaben. Widderumb, wo der geyst gottis ist, da ist freyheit, wie S. Paulus sagt, da darff man keyner lere noch gesetz, und geschicht doch allis, was geschehen soll. Gleych als wer ein gesund, gut gesicht hatt, den darff niemant leren, wie er sehen soll, hatt eyn frey gesicht und mehr, denn yhm all lere da tzu helffen oder geben kündenn. Ist er aber 
ungesundt, da ist die freyheit auß, da kan man nit lere genug finden, die yhn helffen hütten und bewaren, muß auff ein iglichen blick ein eygen sorg und regel haben,das er sehe.

(WA 7, 659, 24-660, 1)

Hierdie mening het egter nie die implikasie gehad dat die wet in sy teologie nie vir die regverdiges enige betekenis gehad het nie. Die wet - beter gesê - die gebod, het wel volgens Luther 'n lerende funksie. Paranese is deel van die Christelike godsdiens. Die Dekaloog was dus vir Luther teologies van wesenlike belang. Hy het op voetspoor van Augustinus die Dekaloog as ontvouing van die dubbele liefdesgebod hanteer, maar in die proses bokant. Augustinus uitgegaan en die praxis van die Christelike etos uitsluitlik aan die hand van die Dekaloog ontwikkel (Peters 1990:53). Om hierdie rede het hy die Dekaloog deel van die Kategismus gemaak, en dit noukeurig uitgelê. In terme van die usus legis tertius of die usus normativus het hy die Dekaloog gebruik as riglyn vir die Christen se sedelike lewe (Joest 1968) ${ }^{8}$. Die Dekaloog of gebod het nou wel nie heilsfunksie nie, maar as bron van die wil van God, as vermaning en as rigtinggewer bly dit belangrik. Luther ken daarom so iets soos die voortbestaan van die wet tot in alle ewigheid. Die verdoemende karakter van die wet sal wel verdwyn, maar die wet as vervulde wet sal bly voortbestaan. Uitdruklik sê hy (WA 39 I, 350, 3-4): Quare lex nunquam in aeternum tollitur, sed manebit vel implenda in damnatis, vel impleta in beatis/'Daarom sal die wet in der ewigheid nooit opgehef word nie, maar dit sal bly as nog te vervulde by die verdoemdes, en as vervulde by die saliges'. Die wet bly dus steeds Woord van God, ten spyte daarvan dat daar streng tussen wet en evangelie onderskei moet word.

Die aanvaarding en aktualisering van hierdie onderskeiding is vir ons van wesenlike belang. Teologisering met behulp van hierdie dialektiese spanning sal ons daarvan bewaar om nie weer 'n stuk kultuur-politieke vroomheid as heilbrengend te waardeer nie.

\section{DIE HELDERHEID VAN DIE SKRIF}

Almal sal saamstem dat die verstaan van die Skrif vanuit die perspektief van die gekompliseerde Lutherse teologie, geen maklike saak is nie. Nogtans het Luther die merkwaardige oortuiging gehad dat die Skrif self helder en duidelik is. Die opvatting dat die Skrif homself uitlê en dat Christus die beslissende inhoud van die Skrif is, vorm die vooronderstelling vir Luther se oortuiging dat die Skrif helder of duidelik is. Hierdie opvatting het Luther eers in sy stryd met Rome openbaar gemaak, alhoewel die 
wortels van sy oortuiging reeds in sy vroeë lesings ${ }^{9}$ merkbaar is. Luther het met behulp van verskillende woorde en beelde aangedui wat hy onder duidelikheid verstaan. In sy stryd met Latomus (1521) het hy die saak kortliks getematiseer en die begrippe synceritas en simplicitas vir 'helderheid' gebruik. In De servo arbitrio het hy die onderwerp breedvoerig behandel. In hierdie geskrif het hy die beeld van drie ligte (tria lumina) gebruik om die helderheid van die Skrif te illustreer. Hy sê dat dit volgens die lig van die natuur (lumen naturae) 'n onoplosbare probleem is dat dit soms met goeie mense sleg en met slegte mense goed kan gaan. Dit is volgens die lig van die genade (lumen gratiae) 'n raaisel waarom God die mens veroordeel wat volgens sy geskape natuur nie anders kan as om te sondig nie. Die lig van die glorie (lumen gloriae) bied egter 'n oplossing vir hierdie dilemmas. In hierdie lig ontdek ' $n$ mens tog dat God altyd met die grootste mate van geregtigheid handel en dat Hy daarom die God van geregtigheid is. Die geregtigheid van God is egter net in die evangelie sigbaar en kan net met die geloof aanvaar word. Hieroor is die Bybel duidelik en helder. Luther sê dus, dat ten spyte van talle onduidelike verse, die Bybel in sy sentrale en saakmakende uitsprake duidelik is. Jesus Christus as geïnkarneerde God ${ }^{10}$ maak die Skrif helder. Hy is die hermeneutiese sleutel om alles te verstaan. Dit beteken nie dat Christus in alle teksverse ingelees moet word nie, maar dat die hele Bybel vanuit ' $n$ Christologiese perspektief verstaan kan word.

Was kann an Erhabenem in der Schrift verborgen bleiben, nachdem die Siegel gebrochen, der Stein von des Grabes Tür gewälzt und damit jenes höchste Geheimnis preisgegeben ist: Christus, der Sohn Gottes, sei Mensch geworden, Gott sei dreifaltig und einer, Christus habe für uns gelitten und werde herrschen ewiglich? Wird das nicht sogar in Elementarschulen bekannt gemacht und dort auch gesungen? Nimm Christus aus der Schrift, was wirst du außerdem noch in ihr finden? Die Dinge also, die in der Schrift enthalten sind, sind alle zur öfentlichen Kenntnis gebracht, wenn auch einige Stellen bisher aus Unkenntnis der Worte dunkel sind.

(WA 18, 606, 24-31)

Sonder hierdie teologiese interpretasie kan die Skrif nie uiterlik helder (claritas externa) wees nie. Uiterlike helderheid is egter nog nie voldoende nie. Daar is ook 'n innerlike helderheid (claritas interna) nodig om die Skrif te verstaan. Die innerlike helderheid word deur die Heilige Gees geskenk in die proses van omgang met die Skrif. Die 
Heilige Gees ontsluit die eintlike betekenis van die Skrif. Hy laat jou die eintlike bedoeling van die Skrif ontdek. Hy laat jou die inhoud van die Bybel glo. Sonder die werk van die Heilige Gees sal jy nie die boodskap van die Bybel verstaan of glo nie. Luther sê:

Wenn du von der inneren Klarheit redest, da versteht kein Mensch auch nur ein Jota in der Schrift, es sei denn, er habe den Geist Gottes. Sonst aber haben alle ein verdunkeltes Herz, so daß sie, auch wenn sie alles aus der Schrift vorzubringen wissen, doch nichts davon verstehen oder erkennen; sie glauben nicht an Gott, noch auch [glauben sie], daß sie die Geschöpfe Gottes seien.

(WA 18, 609, 5-9)

\section{DIE OORBODIGHEID VAN DIE LEERAMP}

Deur die helderheid van die Skrif slegs van gebed, Christologiese hermeneutiek en die werking van die Heilige Gees afhanklik te maak, was sekerlik een van die mees rewolusionêre dinge wat Luther gedoen het. Die implikasie was dat hy 'n streep deur die hele gedagte van die leeramp getrek het. Dit het hom in heftige botsing met die Rooms Katolieke tradisie gebring. Die Rooms-Katolieke het nog altyd geoordeel dat die Bybel nie sonder die hulp van die deur die Gees geleide leeramp saaklik korrek uitgelê en verstaan kan word nie. Luther se Skrifverstaan daarenteen, het neergekom op die verwerping van die gedagte van 'n leeramp. Hy het met die oortuiging gewerk dat die Skrif in wesenlike leeraangeleenthede duidelik is. Teenoor Erasmus het hy (WA 18, 606-609) gesê dat dit absurd is om te beweer dat die Skrif duister is. Die Skrif is helder en duidelik en jy het nie 'n leeramp nodig om alles te laat klop nie. Jy moet net met die hulp van die regverdigingsleer na die bronne ${ }^{11}$ teruggaan, aangesien die Skrif homself uitlê. Luther sê: ... ut sit ipsa per sese certissima, facillima, apertissima, sui ipsius interpres, omnium omnia probans, iudicans et illuminans/'dat die Skrif deur homself absoluut seker, absoluut maklik verstaanbaar, absoluut deursigtig sy eie interpreteerder is, [is waar], [hy] beproef, beoordeel en verlig alle dinge' (WA 7, 97, 2324). Hierdie hele botsing word pragtig geillustreer deur Luther se botsing met Cajetanus oor die aflaatstelsel. In sy verdediging van die aflaatstelsel het Cajetanus hom op die bul van pous Clemens VI uit die jaar 1343 beroep. Hierdie bul (Extravagante genaamd) was as aanhangsel deel van die Roomse kerkreg (Corpus iuris canonici), bindend op kerklike leeruitsprake. Cajetanus se argument was verder dat sy eie interpretasie van die bul met die destyds regerende pous ooreenstem, en daarom moet 
Luther hom aan die leeruitspraak van die leeramp onderwerp. Luther se argument was dat Cajetanus die leer van die aflaat met 'n letterlike Skrifbewys moes begrond, aangesien die bul net met allegoriese Skrifbewyse begrond is (WA 2, 8, 5; 10, 3; 16, $19 ; 22,6)$. Formeel het die twee met mekaar saamgestem dat die Skrif die basis vir leenitsprake is. Maar, vir Cajetanus is 'n Skrifinterpretasie buite die uitlegkompetensie van die pous om 'n ondenkbaarheid. Daar kan volgens Luther nie so iets soos 'n 'geprestabilieerde harmonie' (Lohse 1995:205) tussen kerk en Skrif bestaan nie. Hy argumenteer verder dat ' $n$ interpretasie van die leeramp nie bokant die Skrif self kan staan nie. Die Skrif self, in sy letterlike betekenis, behoort leer in finale instansie te bepaal (Pesch 1983:107-109). Dit beteken egter nie dat Skrif en kerk vir Luther niks met mekaar te make het nie. Inteendeel! Die verskil ${ }^{12}$ is net dat Luther die geloofsuitsprake van die Bybel as beslissend sien en nie die leeruitsprake van 'n ampsdraer nie (Lohse 1995:206-208).

\section{SKRIFVERSTAAN EN ERVARING}

Die verstaan van die Skrif (en veral sonder ampsleiding) is geen maklike onderneming nie. Luther het selfs eenkeer gesê dat dit ' $n$ wonderwerk is wanneer iemand die Bybel reg verstaan (WATR 1, 29, 10). Om hierdie rede het hy naas gebed, Christologie en die werking van die Gees ook nog 'n verdere voorwaarde vir die verstaan en uitleg van die Skrif gegee, naamlik ervaring. Ervaring was vir Luther onontbeerlik ten opsigte van die verstaan van die Skrif. Ek wil graag na twee uitsprake van Luther (een van die vroeë en een van die latere Luther) verwys:

Man soll aber die heilige Schrift nicht nach unserer Vernunft messen, richten, verstehen und deuten, sondern mit dem Gebet fleiBig bedenken und ihr nachtrachten. So sind die Anfechtungen und der Satan auch eine Ursache, daß man sie ein wenig und etlichermaßen durch Übung und Erfahrung verstehen lerne; sonst und ohne das versteht man nimmermehr etwas davon, ob man sie wohl hört und liest.

$(1983: 21=$ WATR 1353$)$

Meine Theologie hab ich nicht auf einmal gelernt, sondern ich hab immer tiefer und tiefer danach forschen müssen. Da haben mich meine Anfechtungen zu gebracht; denn die heilige Schrift kann man nimmermehr verstehen, auBer durch Praxis und Anfechtungen ... So habe ich den Papst, die Universitäten und alle Gelehrten und durch sie den 
Teufel mir am Halse kleben gehabt; die haben mich in die Bibel gejagt, daß ich sie fleißig gelesen und damit ihr rechtes Verständnis endlich erlangt habe. Wenn wir sonst einen solchen Teufel nicht haben, so sind wir nur spekulative Theologen ... Ohne Übung und Erfahrung kann niemand gelehrt sein.

$(1983: 17-18=$ WATR 352)

Luther het hierdie oortuiging dat ervaring (lewenservaring, konflikervaring en probleemervaring) teologie moontlik maak, tot by sy dood gehandhaaf. Twee dae voor sy dood, op 16 Februarie 1546, het Luther volgens Johannes Aurifaber onder die opskrif 'Dat om die Heilige Skrif te verstaan ' $n$ moeilike ding is ${ }^{13}$ ', in Latyn weer die gedagte aangeroer dat mens die Skrif nie sonder lewenservaring en konflikervaring kan verstaan nie. Luther sê dat 'n mens Virgilius nie kan verstaan as ' $n$ mens nie self geboer het nie. Jy kan ook nie vir Cicero verstaan indien jy nie lank in 'n staatsdepartement gewerk het nie. Net so kan jy nie die Bybel verstaan, indien jy nie in die kerklike praktyk met al sy probleme en konflikte gestaan het nie. Die verstaan van die Bybel is dus volgens Luther iets wat groei uit gesprek, stryd en konflik. Die Woord van God kan nie uit ' $n$ kan (soos 'n belydenisskrif) of 'n kruik (soos ' $n$ mening in die verlede) getap word nie. Dit moet met moeite uit die Bybel self gehaal word (kyk Bayer 1991 vir volledigheid).

Dit mag dalk juis hierdie insig van Luther wees wat aan ons in die Nederduitsch Hervormde Kerk van Afrika op hierdie stadium motivering kan gee. Die verwagting behoort te bestaan dat ons wat tans 'n oormaat van ervarings opdoen (polities, maatskaplik, individueel) en wat in binne-kerklike konflikte vasgevang sit, juis die mense is wat dalk die Skrif op 'n wyse kan begin verstaan wat nie net vir ons nie, maar ook vir ander mense van betekenis sal kan wees.

\section{Endnotas}

1 Natuurlik besef ek dat daar nog baie ander, en inderdaad positiewe dinge oor die inspirasieleer gesê kan word. Die polemiek word hier tén één spesifieke wanopvatting gerig.

2 Daar word ten opsigte van die historiese inligting swaar op Pesch (1983:48-70) gesteun.

3 Hierdie metode is klassiek deur Augustinus van Denemarke in die tweede helfte van die 13e eeu saamgevat met die stelling: Littera gesta docet, quid credas, allegoria, Moralis, quid agas, quid speras, anagogia/'Die woorde leer wat gebeur het, wat jy moet leer - die allegorie, die morele (betekenis) wat jy moet doen; wat jy moet hoop — die anagogie' (Sitaat by Pesch 1983:58). 
4 Die ongelooflike is natuurlik dat die Thomiste Cajetanus wat die aflaat verdedig het, en Eck wat die vaevuur verdedig het, nie vir Thomas self geken het nie. Hy (STh I, 1, 10 ad 1) het gesê: 'Und so ergibt sich auch keinerlei Verwirrung in der Heiligen Schrift, da alle (ihre) Sinne auf dem einen gründen, nämlich dem buchstäblichen (Sinn), aus dem allein ein Beweisgrund gewonnen werden kann, nicht aber aus dem, was gemäß der Allegorie gesagt wird, wie Augustinus im Brief gegen den Donatisten Vicentius sagt. Dennoch erwächt daraus der Heiligen Schrift kein Mangel, weil nichts, was zum Glauben notwendig ist, unter dem geistlichen Sinn einbehalten ist, was die Schrift nicht irgendwo offenkundig (auch) im buchstäblichen Sinn überliefert' (sitaat by Pesch 1983:66; kyk ook Lohse 1986 vir 'n volledige oorsig oor Luther se stryd met Cajetanus).

5 Tydens die bespreking van die voordrag is die vraag gevra of mens nie eerder van 'Triadeleer' moet praat nie? Sover ek kon vasstel word daar wel in die Engelse wêreld (Kelly 1993:83-109) oor die 'Divine Triad' binne die konteks van die pre-Niceense teologie gepraat. In die jongste Duitse Dogmengeskiedenis (Hauschild 1995) word daar gewoonweg van 'Trinitätslehre' gepraat. Ferdinand Christiaan Baur (1979) het in sy dogmengeskiedenis wel van die 'Lehre von der Dreieinigkeit' gepraat. Wat Luther self betref het hy by die bewoording 'Trinitätslehre' gehou (Schmid 1983:96-114). Die enigste worsteling wat Luther met terminologie gehad het, was sy afkeur aan die woord 'Dreifaltigkeit' (Hirsch 1964:17-18, Lohse 1995:224-227).

6 Ten spyte van noodsaaklike kritiek van eksegete op teologiese mismaaksels in ons Kerk (bv Breytenbach 1996:700-712), behoort Luther se oortuigings oor eksegese — dogmatiek deur hulle weer ernstig heroorweeg te word.

7 Daar word vandag in die navorsing aanvaar dat ons hier met 'n invoeging van 'n notulehouer te make het wat na aanleiding van Melachthon se drie gebruike van die wet, hierdie term Luther in die mond gelê het (Lohse 1995:293).

8 Ek is vas oortuig van die waarheid van hierdie stelling, ten spyte van die vaste mening van mense soos Martin Honecker (1990:63) dat Luther nie 'n derde gebruik van die wet geken het nie.

9 In die Romeinebriefvoorlesing het hy dit meermale benadruk dat die hele Skrif oor Christus handel — só byvoorbeeld in die 'Scholie' oor Romeine 10:6 (WA 56, 414, 15-18).

10 Ulrich Asendorf (1993) het op grond van 'n ondersoek oor 'Daß diese Worte Christi' van 1527 aangedui, dat Woord en inkarnasie 'n onlosmaaklike samehang in Luther se teologie vorm.

11 Of Luther die histories-kritiese eksegese van vandag in gedagte gehad het, weet mens nie, maar dat hierdie tipe eksegese by Luther sy wortels het, kan seker nie betwyfel word nie.

12 Die hele botsing tussen Luther en Cajetanus is voortreflik deur Lohse in 'n artikel (1986) op skrif gestel. 
13 Virgil den Bucolica und Georgica kann keiner verstehen, der nicht fünf Jahre lang Hirte oder Bauer war.

Cicero in seinen Briefen (so vermute ich) versteht keiner, der nicht zwanzig Jahre lang in eienem bedeutenden Staatswese tätig war.

Die heiligen Schriften meine keiner genug geschmeckt zu haben, der nicht hundert Jahre lang mit den Propheten die Gemeinden geleitet hat.

Diese göttliche Aeneis suche nicht zu ergrinden, sondern bete demütig ihre Spuren an. Wir sind Bettler: hoc est verum.

(WATR 5, 168, 21-36 volgens die vertaling van Bayer 1991:258)

\section{Literatuurverwysings}

Asendorf, U 1993. Das Wort Gottes bei Luther im sakramentalen Zusammenhang patristischer Theologie. KuD 39, 31-47.

Baur, F C [1847] 1979. Lehrbuch der christlichen Dogmengeschichte. Nachdr d 3. Aufl 1867. Darmstadt: Wiss Buchgesellschaft.

Bayer, O 1991. Vom Wunderwerk, Gottes Wort recht zu verstehen. Luthers Letzter Zettel. KuD 37, 258-279.

Breytenbach, A P B 1996. Die gebruik van die Ou Testament in die begronding van die kerk se kultuurtaak. HTS 52/4, 693-714.

Ebeling, G 1960. Zur Lehre vom triplex usus legis in der reformatorischen Theologie, in Wort und Glaube, Band I. 50-68. Tübingen: Mohr.

1983. Wiederentdeckung der Bibel in der Reformation - Verlust der Bibel heute? in Umgang mit Luther, 16-38. Tübingen: Mohr.

Hauschild, W D 1995. Lehrbuch der Kirchen- und Dogmengeschichte, Band 1: Alte Kirche und Mittelalter. Gütersloh: Gütersloher Verlagshaus.

Hirsch, E [1937] 1964. Hilfsbuch zum Studium der Dogmatik: Die Dogmatik der Reformatoren und der altevangelischen Lehrer quellenmäßig belegt und verdeutscht.

4. Aufl. Berlin: De Gruyter

Honecker, M 1990. Einfuihrung in die Theologische Ethik. Berlin: De Gruyter.

Iwand, H J [1974] 1983. Nachgelassene Werke, Band 5: Luthers Theologie. Hrsg v Haar, J. 2. Aufl. München: Kaiser.

Joest, W [1951] 1968. Gesetz und Freiheit: Das Problem des tertius usus legis bei Luther und die neutestamentliche Parainese. Göttingen: Vandenhoeck.

Kelly, J N D [1958] 1993. Early Christian Doctrines. Fifth ed. London: Black. Luther, M 1883vv. Weimarer Ausgabe = WA.

1983. Luther Deutsch. Die Werke Luthers in Auswahl. Hg v Kurt Aland. Band 9: Die Tischreden. Göttingen: Vandenhoeck.

Lohse, B 1986. Cajetan und Luther - Zur Begegnung von Thomismus und Reformation. $K u D 32,150-169$. 
Lohse, B 1995. Luthers Theologie in ihrer historischen Entwicklung und in ihrem systematischen Zusammenhang. Göttingen: Vandenhoeck.

Pesch, O H 1983. Hinführung zu Luther. Mainz: Grünewald.

Peters, A 1990. Kommentar zu Luthers Katechismen, Band 1: Die Zehn Gebote. Göttingen: Vandenhoeck.

Schmid, H [1843] 1983. Die Dogmatik der evangelisch-lutherischen Kirche: Dargestellt und aus den Quellen belegt. Neu hrsg und durchgesehen v Pöhlmann, H G. 10. Aufl. Gütersloh: Mohn. 